\title{
Thorascopic Wedge Resection of the Lung
}

National Cancer Institute

\section{Source}

National Cancer Institute. Thorascopic Wedge Resection of the Lung. NCI Thesaurus.

Code C154873.

A minimally invasive surgical procedure in which video-assisted thoracoscopy is used to remove of a portion of the lung. 